\title{
DIGITAL COMPETENCE THROUGH TWO COURSES AT THE FACULTY OF ARTS: THE EMPIRICAL STUDY
}

\author{
Michal ČERNÝ*, Masarykova Univerzita v Brně, Česká republika
}

\author{
Přijato: 8. 3. 2019 / Akceptováno: 23. 7. 2019
}

Typ článku: Empirická studie

DOI: $10.5507 /$ jtie.2019.005

Abstract: The empirical study analysed data from two courses on digital competence at the Faculty of Arts, Masaryk University. Data was obtained through multiple research tools - tests in the MU information system, selfevaluation questionnaire, Google Analytics and Smartlook. It deals with the topic of digital competences, which theoretically frames DigComp 2.1. It is a quantitative case study on a sample of 144 people. In our case study, we have identified the following research questions: 1) How do students evaluate themselves as part of their digital competencies? 2) Is there a relationship between self-assessment and test results? 3) Can competence domains or individual competencies be identified in which students are significantly better or worse? 4) Can identify the relationship between user interactions with a website and test results and self-evaluation?

The results of our research show a significant imbalance in how the students in digital competencies assessed: from 2.5 points out of 8 in programming to digital technology through cooperation with 4.7 points. At the same time, they suggest that students have significant problems with self-assessment as such. In terms of whole competence domains, students perceive themselves as the strongest in information and data literacy (4.5) and the weakest in problem-solving (3.4).

Key words: Digital Competence, Web Analytics, Google Analytics, DigComp, Self-Assessment.

\section{DIGITÁLNÍ KOMPETENCE OPTIKOU DVOU KURZŮ NA FILOSOFICKÉ FAKULTĚ: EMPIRICKÁ STUDIE}

Abstrakt: Empirická studie je založena na datech ze dvou kurzů věnujicich se digitálním kompetencím na Filosofické fakultě Masarykovy univerzity. Vychází $z$ dat, která byla ziskaná prostřednictvím více výzkumných nástroju - testy $v$ informační systému university, autoevaluační dotaznik, data z Google Analytics a Smartlook. Věnuje se tématu digitálních kompetencí, které teoreticky rámuje DigComp 2.1. Jde o kvantitativní prípadovou studii na vzorku 144 osob. V rámci naši prrípadové studie jsme stanovili následujici výzkumné otázky: 1) Jak sami sebe studenti $v$ rámci digitálních kompetencí hodnotí? 2) Souvisí toto hodnocení $s$ výsledky v testu? 3) Lze identifikovat domény kompetencí, nebo jednotlivé 
kompetence, ve kterých jsou studenti významně slabší či silnější než v jiných? 4) Lze identifikovat vztah mezi uživatelskou interakci se stránkou a výsledky testů či autoevaluace?

Výsledky našeho výzkumu ukazuji značnou nevyrovnanost $v$ tom, jak se studenti v oblasti digitálnich kompetencí hodnotí: od 2,5 bodu z 8 v programováni až po spolupráci skrze digitální technologie s 4,7 body. Současně naznačují, že studenti maji velké problémy se sebehodnocením jako takovým. Z hlediska celých kompetenčnich domén se studenti vnímají jako nejsilnějši v informační a datové gramotnosti $(4,5)$ a nejslabši v řšení problémů $(3,4)$.

Klíčová slova: digitální kompetence, webová analytika, Google Analytics, DigComp, sebehodnocení.

*Autor pro korespondenci: mcerny@phil.muni.cz

\section{1 Úvod}

Digitální kompetence jsou předmětem výzkumného i teoretické zájmu již poměrně dlouhou dobu a nejpozději od roku 2008 je možné vidět jejich širši publikační odezvu také v databázích a odborných časopisech. ${ }^{1}$ Téměř vždy dochází ke shodě v tom, že digitální kompetence jsou něčím, co každý člověk potřebuje $\mathrm{k}$ tomu, aby mohl $\mathrm{v}$ moderní technizované či informatizované společnosti pracovat. Nejde tedy o kompetence směřující k odborníkům na IT, které by bylo možné u části populace přehlížet, ale skutečně o jeden z centrálních kompetenčních trsů, jehož edukační aktuálnost je více než zřejmá. Takto k digitálním kompetencím přistupuje také DigComp (Carretero et al., 2017), tedy Evropský rámec digitálních kompetencí pro občany.

Hovořit o tématu digitální kompetencí v celé jeho šířce a různých kontextech by bylo pro využití v naší studii zbytečné. Přesto, než se pokusíme zaměřit na jednotlivé empirické výsledky naší kvantitativní analýzy, si v úvodu dovolíme nabídnout základní tematické rámování problematiky.

Autorský kolektiv kolem Calvaniho (2008) nabídl studii, která komparovala různé př́stupy ke konstrukci modelů digitálních kompetencí, respektive se soustředila na jejich myšlenková východiska. Digitální kompetence je podle ní možné nahlížet optikou technickou, kognitivní a etickou. Tato diference může sloužit jako základ pro modelování kompetenčních rámců, což ostatně autoři pro př́klad střední školy dělají. Současně autoři zdůrazňují také čtveřici hodnotových východisek, která by bylo vhodné při reflexi digitálních kompetencí zvažovat, totiž snižování diference mezi znalostí a dovedností, dưraz na komplexní myšlení, transdisciplinaritu a syntetické myšlení a citlivost k sociokulturnímu rámci.

Martin (2005) definoval digitální gramotnost jako „povědomí, postoj a schopnost jednotlivce vhodně využívat digitální nástroje $\mathrm{k}$ identifikaci, př́istupu, správě, integraci, vyhodnocování, analýze a syntéze digitálních zdrojů, vytváření nových poznatků a ke komunikaci s ostatními v kontextu konkrétních životních situací, tak aby vytvářel pozitivní

\footnotetext{
${ }^{1}$ Pokud se podíváme např́íklad do databáze Scopus, je tento nárust více než zřetelný - křivka růstu počtu indexovaných publikací pod heslem „digital competence“ je exponenciální. Jen namátkou v roce 2007, šlo o 95 textů, v roce 2013 o 199 textů, v roce 2016 o 337 textů a v roce 2018561 textů.
} 
společenské situace a dokázal tento proces reflektovat.“ Podobný postoj má také Gilster (1997), který jako první použil termín digitální gramotnost.

Cartelli (2009) vychází z podobných pozic jako Calvaniho kolektiv (2008) a zdůrazňuje edukační implikace změn, které digitální prostředí přináší. Zvláštní prostor je věnován problémů, které mají netriviální řešení a povedou $\mathrm{k}$ širšímu mezipředmětovému myšlení, př́ípadně problémům otevřeným. Tak jako Calvani, také Carteli akcentuje př́tomnost etické dimense digitálních kompetencí. Je ale třeba správně chápat ono etické - oběma autorům nejde primárně o filosofickou reflexi, ale o zodpovědnost $\mathrm{v}$ užívání technologií, jak vůči sobě samému, tak také vůči svému okolí.

V naší př́padové studii se budeme držet nejznámějšího modelu digitálních kompetencí, totiž DigComp 2.1: The Digital Competence Framework for Citizens (Carretero et al., 2017), který vzniká na zadání Evropské komise. Zdůrazňuje složku kognitivní, sociální i téma komplexity. Postuluje celek 21 kompetencí, které jsou rozčleněny do pěti dimensí - informační a datová gramotnost, komunikace a spolupráce, tvorba digitálních objektů, bezpečnost a řešení problémů. Model zdůrazňuje nutnost občana disponovat digitálními kompetencemi, pakliže má aktivně a zodpovědně své občanství skutečně vykonávat. Reflektuje tak dlouhodobý evropský diskurs spojující technologie a občanství nejpozději od zprávy Nori a Mince (Zlatuška, 1998).

Rádi bychom na tomto místě také zdůraznili, že nemůžeme věnovat pečlivější prostor vymezení pojmu kompetence, a to ani v několika výše uvedených př́kladech. Obecně lze říci, že se kompetence váže na řešení problémů, je sociálně citlivá a není fixována na jednoduché, konkrétním oborem ohraničené, problémy. Zároveň je nutné říci, že s tímto pojem je v uvedené literatuře zacházeno velice volně.

\section{Uvedení do př́ípadové studie}

$V$ rámci naší empirické studie se zaměříme na dva kurzy na Filosofické fakultě Masarykovi univerzity, které se digitálním kompetencím, tak jak je vymezuje DigComp 2.1 (Carretero et al., 2017), věnují. Motivace pro naše zkoumání je dvojí - chceme nabídnout pohled do prostředí, které není tradičně vnímané jako prostor, kde jsou digitální kompetence $v$ centru zájmu edukace studentů, ale současně by filosofické fakulty měly být prostorem pro rozvoj občanských kompetencí (Veteška 2008).

Pro účely našeho výzkumu (probíhajícího v podzimním semestru 2018) jsme připravili online vzdělávací materiál $\mathrm{v}$ podobě webových stránek vytvořených $\mathrm{v}$ univerzitou používán redakčním systému Umbraco (2019). Studenti měli připravenou strukturu, která kopírovala DigComp - kurz byl rozdělen do pěti částí podle jednotlivých dimensí, které se dále dělily dle kompetencí. Každá dimense měla ještě dvě samostatné podkapitoly nástroje a uvedení do problematiky. Studenti měli na studium tématu vždy dva týdny. Kurz byl ukončený praktickým úkolem, závěrečným dotazníkem, autoevaluačním a znalostním testem. Jednotlivé obsahové kapitoly měli přibližně stejný rozsah, stejně tak kapitoly nástrojové a úvodní, aby bylo možné jejich konzumaci určitým způsobem komparovat.

Online materiál je volně dostupný z https://kisk.phil.muni.cz/digicomp. Kurz byl od počátku koncipován jako webový kurz, (Jiang \& Rafeeq, 2018; Muhametjanova \& Akmatbekova, 2019), který je otevřený, takže s jeho obsahem může interagovat $\mathrm{v}$ podstatě kdokoliv. Našim cílem $\mathrm{v}$ tomto ohledu bylo umožnit studentům se $\mathrm{k}$ materiállim dlouhodobě vracet a současně nabídnout daná témat také širší veřejnosti. V době aktivního běhu kurzu bylo však online prostředí jen málo indexované, takže se na stránkách mimo účastníků nepohybovalo větší množství uživatelů. 
Pro účely kurzu bylo třeba vytvořit pracovní překlad DigComp - jednak aby bylo možné adekvátně pojmenovávat jednotlivé kompetence, ale především pro možnost závěrečného autoevaluačního testování, ve kterém jsme nechtěli vytvářet zbytečnou jazykovou bariéru. Pokud jde o online materiál, je koncipován primárně teoreticky v tom slova smyslu, že má vést studenty $\mathrm{k}$ hlubší reflexi jednotlivých témat. Nemá tedy instruktážní charakter.

V rámci naší př́ípadové studie jsme stanovili následující výzkumné otázky:

1. Jak sami sebe studenti v rámci digitálních kompetencí hodnotí?

2. Souvisí toto hodnocení s výsledky v testu?

3. Lze identifikovat domény kompetencí, nebo jednotlivé kompetence, ve kterých jsou studenti významně slabší či silnější než v jiných?

4. Lze identifikovat vztah mezi uživatelskou interakcí se stránkou a výsledky testů či autoevaluace?

Na tomto místě bychom měli upřesnit význam a teoretické zakotvení jednotlivých otázek. Pokud jde o sebehodnocení, představuje základní referenční hladinu toho, jak $\mathrm{z}$ hlediska kompetencí student sám sebe vidí. Jakkoli existují různé výzkumné nástroje na měření digitálních kompetencí, nelze o žádném z nich hovořit jako o standardizovaném nástroji.

$\mathrm{Z}$ tohoto důvodu také výsledky testu nevnímáme jako výsledek sám o sobě, který by nám umožnil identifikovat úroveň kompetencí, ale chceme je vztáhnout $\mathrm{k}$ autoevaluaci a sledovat více korelaci mezi oběma hodnotami než jejich absolutní výsledek. Formálně každý student odpovídal na dvě (náhodně vybrané) otázky ke každé kompetenci.

Zájem na třetí výzkumné otázce je nesen dvěma aspekty. Tím prvním je prozkoumání „náročnosti“ kompetenčních domén (či jednotlivých kompetencí) pro studenty FF MU. Zde je dopředu snadno identifikovaná hypotéza, že by měli být silní v oblasti práce $\mathrm{s}$ informacemi, a naopak nejhorší výsledky lze očekávat u programování. V neposlední řadě je zde ale také zájem edukační - pokud bychom zjistili významné rozdíly, je možné kurz pro př́iští běh upravit či rozšriřit tak, aby rámec byl ve vztahu ke vnímaným kompetencím studentů skutečně referenční.

Zdůvodnění čtvrté výzkumné otázky provedeme až v metodologickém vymezení. Zde si obecně dovolíme říci, že výzkumem studijního chování se dlouhodobě zabýváme (Černý, 2018) a možnost využití dat o vnímání či výsledcích studentů pro intepretaci dat z návštěvnosti webu získaných z Google Analytics a Smartolook se jeví jako velice výhodná a zajímavá. A to především v kontextu toho, co vlastně studenti $z$ hlediska svého studijního chování považují za podstatné studovat. Budeme pracovat s hypotézou, že kompetenční domény, ve kterých budou úspěšní budou mít vyšší míru interakce než ty, ve kterých jsou výsledky horší. Motivace pro takto formulovanou hypotézu je dvojí: a) předpokládáme edukační efekt materiálů a b) předpokládáme větší míru zájmu v oblasti, která studentům, ,jde“.

\section{Popis vzorku}

V rámci naší př́padové studie pracujeme se dvěma výzkumnými vzorky. Tím prvním jsou studenti bakalářského studia oboru Informační studia a knihovnictví na FF MU, kteří absolvují povinný předmět VIKBA14 Digitální kompetence, který je zařazený do třetího semestru doporučeného studijního plánu. Objevuje se v něm několik repetentů (4) a jeden student $\mathrm{z}$ jiného oboru. Celkem šlo o 52 osob z nichž k test plnilo $41 \mathrm{z}$ nich. Kurz byl organizovaný formou blended learningu (Garrison \& Kanuka, 2004; Garrison 
\& Vaughan, 2008), kde mimo online studium byly jednou týdně $\mathrm{k}$ dispozici také přednášky, které kontextualizovaly nebo doplňovaly určitá témata.

Druhým vzorkem byli studenti nového kurzu KPI33 Kurz rozvoje digitálních kompetencí, který byl vypsán poprvé, byl čistě e-learninogový a otevřený pro všechny studenty univerzity jako volitelný předmět. Kurzu se účastnilo celkem 94 studentů, z nichž 60 bylo z Filozofické fakulty, 11 z Prŕrodovědecké fakulty, 7 z Ekonomicko-správní fakulty, 2 z Pedagogické fakulty, 6 z Fakulty informatiky a po čtyřech z Právnické fakulty a Fakulty sociálních studií Masarykovy Univerzity v Brně. 74 studentů bylo presenčních a 20 kombinovaných, což odkazuje ke skutečnosti, že e-learningové kurzy nejsou atraktivní pouze pro kombinované studenty. 41 bylo z navazujícího magisterského studia, 44 z bakalářského. Specifické bylo, že 37 studentů jsou studenti informačních studií a knihovnictví (ISK), tedy podstatná část z nich nějakou formou výuky ve VIKBA14 prošla. Kurz jako takový byl nový pro všechny studenty a vzorek byl plně disjunktní. Test vyplňovalo 67 studentů.

Celkový vzorek, se kterým jsme pracovali, byl tedy 108 studentů na konci kurzu a více než 146 studentů na začátku. (přesné číslo není možné uvést nebot' systém neumí evidovat studenty, kteří se v průběhu prvních čtrnácti dní do kurzu přihlásí a následně si jej odepíší, takže 146 je počtem studentů, kteři v kurzu zůstali zapsaní po konci změn $\mathrm{v}$ zápisu předmětů) Online prostř̌edí bylo pro obě studijní skupiny společné a uživatele v něm nejsme schopni efektivně rozlišovat, ani to nepovažujeme za eticky vhodné, byt' existují způsoby, jak by bylo možné sledovat chování jednotlivých uživatelů.

\section{Sběr a zpracování dat}

Data pro naši př́padovou studii pocházejí ze čtyř různých nástrojů, což také ovlivňuje to, jakým způsobem mohou být zpracovávána. První dva popsané nástroje spolu se způsobem sběru a zpracování dat jsou primárně určené pro odpovědi na výzkumné otázky $1-3, k$ analýze 4 . otázky je třeba ještě připojit data $\mathrm{z}$ dalších dvou nástrojů.

Autoevaluační dotazník byl realizovaný v Informačním systému Masarykovy univezity jako odpovědník. Studenti museli odpovědět na všech 21 otázek, aby mohli ukončit kurz. Jednotlivé otázky jsou překladem kompetencí v DigComp a student tak mohl jejich obsah snadno porovnávat s jednotlivými texty. Zajímavostí je, že nepracuje s běžnou Likertovou škálou, ale na rozmezí stupně 1 až 8 nabízí poměrně pečlivé popisky toho, co daná úroveň kompetence znamená. $Z$ hlediska interpretace dat je třeba zdůraznit, že zatímco úroveň 1-6 směřují $\mathrm{k}$ běžnému aktivnímu občanství a lze formulovat oprávněný ideální požadavek na to, aby v každé kompetenci dosahoval jedinec úrovně šest, tak poslední dva stupně jsou spojené s pracovním prostředím a jsou designované jako výběrové - nedomnívám se, že by bylo možné, aby někdo měl kompetence v úrovni 8 ve všech nebo ve většině položek. Popisy jednotlivých stupňủ jsou pro každou kompetenci jiné, byt' sledují společné schéma náročnosti. Pro účely autoevaluačního testu jsme škálu nastavili jako devítistupňovou, stím, že jsme stupni jedna předřadili ještě variantu s absencí dané kompetence.

Data bychom mohli přiřazovat konkrétním uživatelům (studentům), což ale z důvodu etických i metodologických není nyní důležité ani vhodné. $Z$ informačního systému jsme provedli export odpovědí studentů. $Z$ nich jsme pak počítali průměr každé kompetence následujícím způsobem: úroveň kompetence (na škále 0 až 8 ) jsme vynásobili četností odpovědí (viz tabulky1 a 2) a tyto hodnoty jsme sečetli, a následně podělili počtem odpovědí. 
Tato metoda zpracování vyžaduje dvě poznámky - v př́padě absence kompetence jsme daný počet násobili nulou. Druhá informace souvisí $\mathrm{s}$ tím, že předpokládáme lineárnost škály, což je ale silně aproximativní charakter. Ve škále se nacházejí zlomy, kdy dvě kompetenční úrovně jsou si vždy blíže než další a tvoří jisté klastry. Tuto skutečnost jsme ale neuvažovali ve zpracování dat. Výsledek jsme analyzovali jak dle jednotlivých kompetencí, tak také v rovině domén. Získaná data nám umožňují také komparovat studenty VIKBA14 a KPI33 mezi sebou.

Na odpovědníky mohli studenti odpovídat od 16. 12. 2018 do 31.1. 2019.

Znalostní test byl také realizovaný jako autorizovaný a autentizovaný v IS univerzity. Studenti obou kurzů měli stejné sady otázek. Test byl na omezený čas a každý student odpovídal na sadu 42 otázek, které byly náhodně vybrané a seřazené. Vždy ale platilo pravidlo, že každá kompetence je testovaná dvěma otázkami. Studenti VIKBA14 měli na test jeden pokus, studenti KPI33 až tři, pokud nedosáhli minimální bodové hladiny 23 bodů.

Testové otázky obsahovaly čtyři možné odpovědi, z nichž pouze jedna byla správná. Za zodpovězenou otázku student získal jeden bod v prrípadě korektní odpovědi, v př́padě chybné nebo nezodpovězení získal bodủ 0 . Tím, že test neměl charakter standardizovnaého testu, není možné z dat, která jsme z něj získali, usuzovat na absolutní úroveň kompetence, ale umožňuje nám spíše sledovat obecnější charakteristiky. Abychom nepřesnost nástroje sníżili (omezili vliv jednotlivých otázek), tak jsme při zpracování dat postupovali následujícím způsobem.

U každé otázky jsme určili její korektnost (jaké procento studentů na ni odpovědělo správně). V druhém kroku jsme jednotlivé otázky přiřadili doménám kompetencí a spočítali z nich průměr. Výsledné číslo je tedy průměrnou korektností odpovědí v otázkách např́č jednotlivými kompetencemi. Minimem je šestnáct a maximem dvacet devět průměrovaných otázek. Získaná data nám umožňují také komparovat studenty VIKBA14 a KPI33 mezi sebou.

Na odpovědníky mohli studenti odpovídat od 16. 12. 2018 do 31.1.2019.

Zatímco předchozí dva nástroje pracovaly s daty na konci kurzu a umožnily evaluovat výstupy studentů, tak následující dva nástroje slouží ke sběru dat v průběhu celého kurzu. Data jejich prostřednictvím byla získávána od 1.9. 2018 do 6. 2. 2019. Také není možné rozlišit studenty VIKBA14 a KPI33. Současně je třeba zdůraznit, že nejde o klasické pojetí learning analytics, tak jak je známé napríílad u Siemense (2011, 2012), Fergusona (2012) či Eliase (2001).

Google Analytics jsou zřejmě nejvýznamnějším nástrojem pro práci s webovou analytikou (Clifton, 2012; Cutroni, 2010; Ledford et al., 2011). Umožňují na stránky (v našem př́padě na web kurzu) umístit kód a na základě něj analyzovat, jakým zpưsobem $\mathrm{s}$ obsahem studenti pracují. Pro naši analýzu jsem se rozhodli zvolit výběr návštěvníků, kteří nevykazují tzv. okamžité opuštění stránky. Celkem bylo takto ve zvoleném období znamenáno 976 návštěvníků (jde o uživatele, který není spojený s cookies - tedy o př́stup $\mathrm{z}$ různého zařízení, př́ípadně $\mathrm{z}$ anonymního módu atp.). Průměrný čas na jednu návštěvu na stránce byl 14 minut, což odpovídá 6,3 zobrazeným stránkám.

Tento nástroj také umožňuje analyzovat průměrný čas strávený na jedné stránce, což byla první klíčová metrika, která pro nás byla zajímavá a kterou jsme mohli pro naše analýzy využít. $Z$ dat, která máme dále $k$ dispozici by bylo možné ř́́ci, že nejtypičtějšími zájmy studentů (analyzováno bylo 27 \% z nich) jsou recenze filmů, online video, slovníky a encyklopedie, populární hudba a literatura. Slovenštinu má jako primární jazyk na 
počítači nastaveno pouze necelých $5 \%$ uživatelů. Nejvíce návštěv je z Brna 515 a z Prahy 203. Významnou informací může být ještě počet návštěv z mobilních zařízení, který byl asi $25 \%$ a v průběhu celého semestru byl přibližně konstantní.

Každá naměřená stránka v Google Analytics odpovídá jedné kompetencí, případně úvodní stránce $\mathrm{k}$ doméně a nástrojům. Je tedy možné s nimi pracovat jak po jednotlivých kompetencích, tak také po celých doménách.

Smartlook je nástroj, který umožňuje tvořit heatmapy ${ }^{2}$, analyzovat pohyb kurzoru po stránce anebo evidovat počet kliknutí (Černý, 2018). V námi provedené analýze využíváme poslední možnost. Pomocí Smartlook získáme data za kliknutí na stránku a přenášíme je do tabulky. Export není př́mý, protože evidujeme pouze kliknutí, která je možné vnímat jako měřený zájem - bylo tedy tř̌eba provést ručně analýzu kliknutí mimo horní a dolní navigační část stránky. Tato analýza byla prováděna dvakrát, aby nedocházelo $\mathrm{k}$ chybám $\mathrm{v}$ měření. Lze očekávat, že systematická chyba bude u všech stránek podobná (jsou technicky identicky řešené) a chyba při sčítání bude jeden až dva kliky na stránku, což je pod hranicí statické významnosti. Tak jako u Google Analytics, tak také Smartlook je založený na př́ítomnosti speciálního kódu na konkrétní stránce.

\section{Výsledky a jejich interpretace}

První výzkumnou otázkou bylo, jak sami sebe studenti v rámci digitálních kompetencí hodnotí? Kurz byl primárně zamýšlen pro dosažení úrovně kompetencí mezi 5.-6. stupněm v průměru. ${ }^{3}$ Pro zodpovězení na tuto otázku je možné využít data $\mathrm{z}$ autoevaluačního dotazníku.

Pro kurz KPI33 vyšly následující výsledky:

\begin{tabular}{|l|c|c|c|c|c|c|c|c|c|c|}
\hline $\begin{array}{l}\text { Název kompetence / } \\
\text { stupeň [četnost] }\end{array}$ & $\mathbf{0}$ & $\mathbf{1}$ & $\mathbf{2}$ & $\mathbf{3}$ & $\mathbf{4}$ & $\mathbf{5}$ & $\mathbf{6}$ & $\mathbf{7}$ & $\mathbf{8}$ & $\begin{array}{c}\text { Prům. } \\
\text { [b.] }\end{array}$ \\
\hline $\begin{array}{l}\text { Vyhledávání } \\
\text { informací a jejich } \\
\text { filtrování }\end{array}$ & 0 & 1 & 6 & 9 & 17 & 8 & 19 & 4 & 0 & $\mathbf{4 , 5}$ \\
\hline Hodnocení informací & 0 & 1 & 3 & 6 & 21 & 10 & 17 & 5 & 1 & $\mathbf{4 , 8}$ \\
\hline Organizace informací & 0 & 1 & 8 & 1 & 21 & 12 & 17 & 3 & 1 & $\mathbf{4 , 6}$ \\
\hline $\begin{array}{l}\text { Interakce skrze } \\
\text { digitální prostředí }\end{array}$ & 0 & 1 & 5 & 8 & 17 & 6 & 21 & 4 & 2 & $\mathbf{4 , 7}$ \\
\hline $\begin{array}{l}\text { Sdílení skrze } \\
\text { technologie }\end{array}$ & 0 & 1 & 5 & 11 & 12 & 7 & 23 & 5 & 0 & $\mathbf{4 , 7}$ \\
\hline $\begin{array}{l}\text { Zapojení se do } \\
\text { aktivního občanství } \\
\text { prostřednictvím }\end{array}$ & 3 & 2 & 12 & 25 & 6 & 2 & 11 & 3 & 0 & $\mathbf{3 , 5}$ \\
\hline
\end{tabular}

\footnotetext{
${ }^{2}$ Heatmapou rozumíme grafickou representaci určitého fenoménu (v našem př́padě pohybu kurzoru na stránce nebo počet kliknutí na stránce) ve formě barevné škály - od modré jako nejméně intenzivní až po červenou - umístěnou nad danou webovou stránkou. Označení nemá žádný český ustálený překlad a čtenářům bude dobře známo z předpovědi počasí, kde zachycuje barevnou nebo srážkovou škálu nad mapovým podkladem.

${ }^{3} \mathrm{~V}$ celém textu budeme uvádět u hodnoty kompetence číslo bez jednotky, kterým míníme „počet bodů“, respektive autoevaluací stanovenou úroveň dané kompetence.
} 


\begin{tabular}{|l|c|c|c|c|c|c|c|c|c|c|}
\hline $\begin{array}{l}\text { digitálních } \\
\text { technologií }\end{array}$ & & & & & & & & & & \\
\hline $\begin{array}{l}\text { Spolupráce skrze } \\
\text { digitální technologie }\end{array}$ & 0 & 1 & 2 & 9 & 13 & 7 & 23 & 7 & 2 & $\mathbf{5 , 0}$ \\
\hline Netiketa & 1 & 0 & 7 & 16 & 15 & 8 & 13 & 4 & 0 & $\mathbf{4 , 2}$ \\
\hline $\begin{array}{l}\text { Správa digitální } \\
\text { identity }\end{array}$ & 1 & 1 & 8 & 11 & 26 & 3 & 10 & 4 & 0 & $\mathbf{4 , 0}$ \\
\hline $\begin{array}{l}\text { Vytvářní digitálních } \\
\text { objektů }\end{array}$ & 1 & 3 & 5 & 10 & 12 & 7 & 19 & 6 & 1 & $\mathbf{4 , 5}$ \\
\hline $\begin{array}{l}\text { Integrace služeb a } \\
\text { obsahu }\end{array}$ & 3 & 4 & 10 & 7 & 21 & 3 & 14 & 1 & 1 & $\mathbf{3 , 8}$ \\
\hline $\begin{array}{l}\text { Licence a autorská } \\
\text { práva }\end{array}$ & 0 & 5 & 13 & 15 & 20 & 2 & 6 & 3 & 0 & $\mathbf{3 , 5}$ \\
\hline Programování & 14 & 19 & 9 & 4 & 6 & 3 & 4 & 3 & 2 & $\mathbf{2 , 3}$ \\
\hline Ochrana zař́zení & 0 & 7 & 10 & 17 & 15 & 7 & 7 & 1 & 0 & $\mathbf{3 , 5}$ \\
\hline Ochrana osobních dat & 1 & 8 & 7 & 18 & 12 & 2 & 12 & 3 & 1 & $\mathbf{3 , 7}$ \\
\hline $\begin{array}{l}\text { Ochrana zdraví a } \\
\text { psychické pohody }\end{array}$ & 1 & 2 & 16 & 10 & 19 & 7 & 7 & 2 & 0 & $\mathbf{3 , 6}$ \\
\hline $\begin{array}{l}\text { Ochrana životního } \\
\text { prostředí }\end{array}$ & 3 & 4 & 7 & 14 & 19 & 5 & 10 & 2 & 0 & $\mathbf{3 , 7}$ \\
\hline $\begin{array}{l}\text { Řešení technických } \\
\text { problémů }\end{array}$ & 2 & 9 & 8 & 18 & 9 & 5 & 9 & 4 & 0 & $\mathbf{3 , 5}$ \\
\hline $\begin{array}{l}\text { Nalezení výzev } \\
\text { a možnost jejich } \\
\text { uskutečnění } \\
\text { s technologiemi }\end{array}$ & 1 & 4 & 16 & 14 & 14 & 3 & 9 & 3 & 0 & $\mathbf{3 , 5}$ \\
\hline $\begin{array}{l}\text { Kreativní využití } \\
\text { technologií }\end{array}$ & 0 & 6 & 18 & 16 & 7 & 7 & 6 & 4 & 0 & $\mathbf{3 , 4}$ \\
\hline $\begin{array}{l}\text { Nalezení mezer } \\
\text { v digitálních } \\
\text { kompetencích }\end{array}$ & 1 & 9 & 11 & 16 & 17 & 5 & 5 & 0 & 0 & $\mathbf{3 , 2}$ \\
\hline
\end{tabular}

Tab. č. 1: Autoevaluačni hodnoceni studentů kurzu KPI33.

Průměrná kompetence $\mathrm{z}$ autoevaluace studentů je na úrovni 3,9 bodů, což odpovídá přibližně schopnosti samostatně řešit problémy s využitím digitálních technologií, ovšem bez možnosti nebo snahy pomoci někomu druhému.

Pro studenty VIKBA14 vyšla data následovně:

\begin{tabular}{|l|c|c|c|c|c|c|c|c|c|c|}
\hline $\begin{array}{l}\text { Název kompetence / } \\
\text { stupeň [četnost] }\end{array}$ & $\mathbf{0}$ & $\mathbf{1}$ & $\mathbf{2}$ & $\mathbf{3}$ & $\mathbf{4}$ & $\mathbf{5}$ & $\mathbf{6}$ & $\mathbf{7}$ & $\mathbf{8}$ & $\begin{array}{c}\text { Prům. } \\
{[\mathbf{b . ]}}\end{array}$ \\
\hline $\begin{array}{l}\text { Vyhledávání informací } \\
\text { a jejich filtrování }\end{array}$ & 0 & 1 & 1 & 8 & 16 & 5 & 1 & 0 & 0 & $\mathbf{4 , 3}$ \\
\hline Hodnocení informací & 0 & 1 & 2 & 8 & 13 & 8 & 6 & 3 & 0 & $\mathbf{4 , 3}$ \\
\hline
\end{tabular}




\begin{tabular}{|l|c|c|c|c|c|c|c|c|c|c|}
\hline Organizace informací & 0 & 0 & 4 & 8 & 13 & 4 & 9 & 3 & 0 & $\mathbf{4 , 4}$ \\
\hline $\begin{array}{l}\text { Interakce skrze } \\
\text { digitální prostředí }\end{array}$ & 0 & 1 & 3 & 8 & 12 & 8 & 7 & 2 & 0 & $\mathbf{4 , 3}$ \\
\hline $\begin{array}{l}\text { Sdílení skrze } \\
\text { technologie }\end{array}$ & 1 & 0 & 6 & 11 & 6 & 10 & 3 & 4 & 0 & $\mathbf{4 , 0}$ \\
\hline $\begin{array}{l}\text { Zapojení se do } \\
\text { aktivního občanství } \\
\text { prostřednictvím } \\
\text { digitálních technologií }\end{array}$ & 1 & 3 & 9 & 9 & 11 & 3 & 3 & 1 & 1 & $\mathbf{3 , 4}$ \\
\hline $\begin{array}{l}\text { Spolupráce skrze } \\
\text { digitální technologie }\end{array}$ & 0 & 1 & 4 & 4 & 16 & 6 & 7 & 2 & 1 & $\mathbf{4 , 4}$ \\
\hline Netiketa & 0 & 0 & 4 & 9 & 13 & 8 & 4 & 3 & 0 & $\mathbf{4 , 2}$ \\
\hline $\begin{array}{l}\text { Správa digitální } \\
\text { identity }\end{array}$ & 0 & 3 & 3 & 8 & 13 & 6 & 5 & 3 & 0 & $\mathbf{4 , 0}$ \\
\hline $\begin{array}{l}\text { Vytvářní digitálních } \\
\text { objektů }\end{array}$ & 0 & 1 & 4 & 11 & 10 & 5 & 5 & 5 & 0 & $\mathbf{4 , 2}$ \\
\hline $\begin{array}{l}\text { Integrace služeb a } \\
\text { obsahu }\end{array}$ & 0 & 0 & 12 & 10 & 11 & 3 & 3 & 2 & 0 & $\mathbf{3 , 5}$ \\
\hline $\begin{array}{l}\text { Licence a autorská } \\
\text { práva }\end{array}$ & 0 & 2 & 7 & 9 & 16 & 2 & 4 & 1 & 0 & $\mathbf{3 , 6}$ \\
\hline Programování & 4 & 12 & 10 & 5 & 1 & 0 & 5 & 3 & 1 & $\mathbf{2 , 7}$ \\
\hline Ochrana zařízení & 0 & 3 & 10 & 8 & 8 & 3 & 7 & 2 & 0 & $\mathbf{3 , 7}$ \\
\hline Ochrana osobních dat & 1 & 1 & 7 & 12 & 7 & 3 & 7 & 3 & 0 & $\mathbf{3 , 8}$ \\
\hline $\begin{array}{l}\text { Ochrana zdraví a } \\
\text { psychické pohody }\end{array}$ & 2 & 3 & 6 & 8 & 15 & 3 & 5 & 0 & 0 & $\mathbf{3 , 5}$ \\
\hline $\begin{array}{l}\text { Ochrana životního } \\
\text { prostředí }\end{array}$ & 0 & 1 & 9 & 7 & 16 & 6 & 2 & 0 & 0 & $\mathbf{3 , 6}$ \\
\hline $\begin{array}{l}\text { Řešení technických } \\
\text { problémů }\end{array}$ & 0 & 7 & 11 & 9 & 5 & 3 & 2 & 3 & 1 & $\mathbf{3 , 2}$ \\
\hline $\begin{array}{l}\text { Nalezení výzev } \\
\text { a možnost jejich } \\
\text { uskutečnění } \\
\text { s technologiemi }\end{array}$ & 0 & 4 & 7 & 13 & 5 & 2 & 9 & 1 & 0 & $\mathbf{3 , 6}$ \\
\hline $\begin{array}{l}\text { Kreativní využití } \\
\text { technologí́ }\end{array}$ & 1 & 2 & 9 & 10 & 9 & 4 & 3 & 3 & 0 & $\mathbf{3 , 5}$ \\
\hline $\begin{array}{l}\text { Nalezení mezer } \\
\text { v digitálních } \\
\text { kompetencích }\end{array}$ & 0 & 4 & 9 & 5 & 11 & 5 & 5 & 2 & 0 & $\mathbf{3 , 7}$ \\
\hline
\end{tabular}

Tab. č. 2: Autoevaluačni hodnocení studentů kurzu VIKBA14.

$\mathrm{V}$ př́ípadě kurzu VIKBA14 vychází průměrná kompetence $\mathrm{v}$ podstatě totožně na 3,8 b., ovšem zajímavé je, že s menším rozptylem než v př́ípadě prvního kurzu. 
$\mathrm{V}$ případě průměrného sebehodnocení kompetencí je možné říci, že nejsilnější se studenti cítí v oblasti informační a datové gramotnosti (což odpovídá také jejich studijnímu zaměření) a to na úrovni 4,5 b., následuje komunikace a spolupráce s 4,2 b. a další tři domény mají průměrné skóre $\mathrm{v}$ rozmezí 3,4-3,6 b. V této souvislosti je zajímavé, že studenti sami sebe nehodnotí $\mathrm{v}$ oblasti práce $\mathrm{s}$ informacemi výše, nebot' předmětem jejich studia je (i optikou povinných kurzů) ve většině právě vyhledávání, organizace a hodnocení informací. To vyvolává otázku, zda je právě tato doména nastavená správně, pokud se v ní nenachází lidé, kteří jsou profesionály v této oblasti ve větší míře v rozmezí stupnice 5-8 b.

Až na programování, které je výjimkou, nedochází $\mathrm{k}$ tomu, že by $\mathrm{v}$ některých kompetencích studenti neměli žádné zastoupení ve větší míře. $V$ případě KPI33 může být dané vysoké skóre dané tím, že studenti z jiných fakult žádný programovací kurz (mimo Fakultu informatiky) mít nemusí, zatímco silná populace studentů informačních studií takovým předmětem prochází typicky v prvním ročníku.

Druhou výzkumnou otázkou je, zda a jak souvisí toto hodnocení s výsledky v testu? Také zde může být odpověd' poměrně prímočará. Postupovali jsme tak, že jsme v souladu s DigComp kompetence setrrídili do dimensí a informace zanesli do následující tabulky.

\begin{tabular}{|l|l|l|l|l|}
\hline \multicolumn{1}{|c|}{ Doména } & $\begin{array}{l}\text { Správnost } \\
{[\%]}\end{array}$ & $\begin{array}{l}\text { Sebehodnocení } \\
\text { VIKBA14 [b.] }\end{array}$ & $\begin{array}{l}\text { Sebehodnocení } \\
\text { KPI33[b.] }\end{array}$ & $\begin{array}{l}\text { Sebehodnocení } \\
\text { celkem [b.] }\end{array}$ \\
\hline $\begin{array}{l}\text { Informační } \\
\text { a datová } \\
\text { gramotnost }\end{array}$ & 65,9 & 4,3 & 4,6 & 4,5 \\
\hline $\begin{array}{l}\text { Komunikace } \\
\text { a spolupráce }\end{array}$ & 64,5 & 4,1 & 4,4 & 4,2 \\
\hline $\begin{array}{l}\text { Tvorba } \\
\text { digitálního } \\
\text { obsahu }\end{array}$ & 72,6 & 3,5 & 3,5 & 3,5 \\
\hline Bezpečnost & 72,8 & 3,6 & 3,6 & 3,6 \\
\hline $\begin{array}{l}\text { Řešení } \\
\text { problémů }\end{array}$ & 66,6 & 3,5 & 3,4 & 3,4 \\
\hline
\end{tabular}

Tab. č. 3: Komparace korektnosti odpovédí a sebehodnocení v kurzech.

Testové otázky byly koncipované typově tak, aby ověřovaly podobné vrstvy Bloomovy taxonomie a jejich cílem byla především znalost klíčových konceptů, jmen, služeb a pojmů, př́padně schopnost adekvátní reakce na jednoduchou situaci. Jak je patrné $\mathrm{z}$ tabulky, námi provedené měření nevedlo $\mathrm{k}$ žádné korelaci mezi sebehodnocením a správností odpovědí $\mathrm{v}$ testu. Jednotlivé možné vazby jsou na úrovni pěti prvků zcela náhodné.

Třetí otázku jsme již částečně začali rozkrývat výše - Lze identifikovat domény kompetencí, nebo jednotlivé kompetence, ve kterých jsou studenti významně slabší či silnější než v jiných? Pokud bychom se přidrželi sebehodnocení, tak jednoznačně nejhůře dopadá Programování - 2,5 b., následované Řešením technických problém s 3,3 b. Zde je dobré si povšimnout toho, že jediné dvě „technické“ kompetence jsou studenty vnímané 
nejhưře, což do jisté míry odráží běžně vnímaný narativ filozofické fakulty. Za povšimnutí stojí také rozdíl téměř celé jedné úrovně mezi těmito položkami.

Za přkkvapivý je možné považovat výsledek třetí nejhorší totiž Nalezení mezer $\mathrm{v}$ digitálních kompetencích $(3,4$ b.). Tato kompetence je v DigComp konstituována jako sebe reflektivní, směrující ke schopnosti reflexe vlastní situace, znalostí a dovedností (prípadně druhých) a schopnosti se v nich zlepšovat.

Naopak nad hranicí 4,5 b. se umístilo hodnocení informací (4,5b.), Interakce skrze digitální prostředí $(4,5$ b.) a Spolupráce skrze digitální technologie $(4,7$ b.). Data je možná vnímat tak, že studenti jsou již plně součástí sítové generace a že spolupráci a interakci vnímají jako něco, v čem se cítí doma. Potěsitelný je též výsledek u Hodnocení informací, který je možné číst jako aktivní odpověd’ studentů na problémy spojené s dezinformacemi. Obecně nad hranicí 4 skončily také zbylé dvě kompetence směřující $\mathrm{k}$ práci s informacemi - Vyhledávání informací a jejich filtrování $(4,4$ b.) a Organizace informací $(4,5$ b.), což dobře odpovídá profilu studentů.

Celkovou bilanci za oba kurzy dohromady uvádíme v níže v grafu.

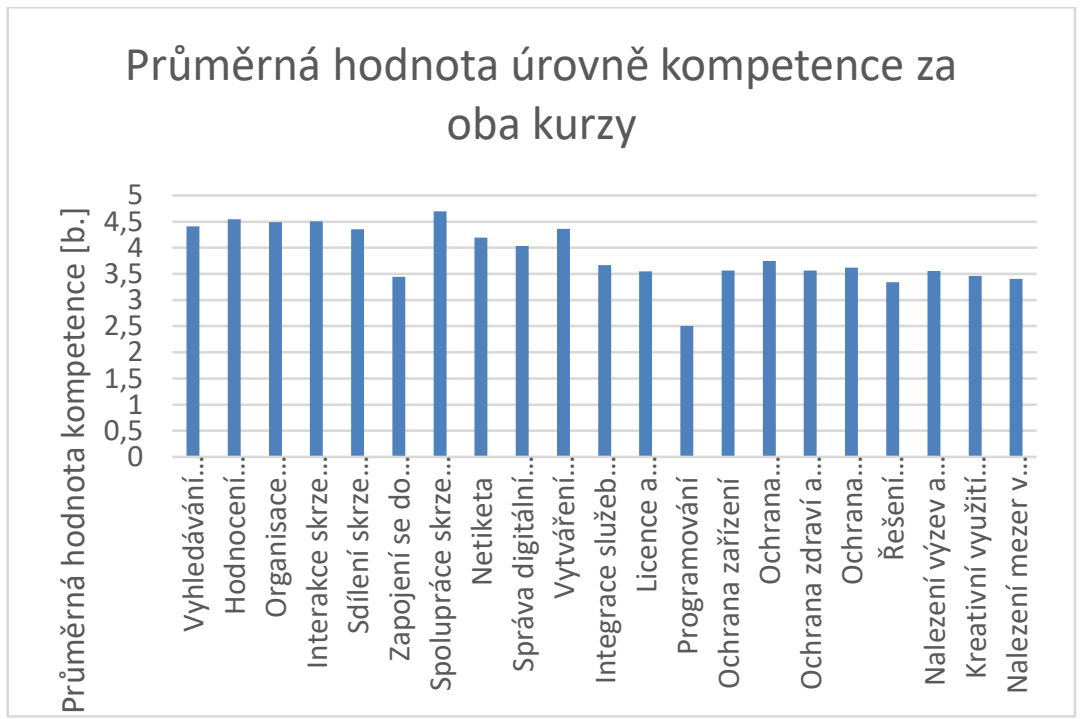

Graf č. 1: Prưměrná hodnota úrovně kompetence dle autoevaluace za oba kurzy dohromady.

Poslední čtvrtá otázka je z hlediska analýzy dat zřejmě nejnáročnější: Lze identifikovat vztah mezi uživatelskou interakcí se stránkou a výsledky testů či autoevaluace? Abychom na tuto otázku mohli odpovědět, je třeba ji převést na snáze operacionalizovatelnou variantu, tedy jak souvisí jejich studijní chování na stránkách kurzu a) s časem stráveným na stránce, b) s počtem interakcí (kliknutí) v přepočtu na návštěvu, c) s počtem interakcí (kliknutí) v přepočtu na návštěvu a jednotku času? Jak již bylo řečeno, počet kliknutí, jako základní interakční jednotku budeme získávat ze Smartlook, a čas, př́ípadně počet 
zobrazení stránky z Google Analytics. Datům z Google Analytics ve vztahu ke studijnímu chování se věnují neprŕiliš četné studie (Romanowski \& Konak, 2016; Luo, Rocco \& Schaad, 2015; Mc Guckin \& Crowley, 2012; Černý, 2018).

Než se přesuneme k samotné interpretaci a presentaci dat, rádi bychom uvedli některé údaje, které souvisejí pouze s online prostředím, bez zvažování vztahu k zájmům nebo výsledkům studentů. Zřejmě nejjednodušší metrikou je čas strávený na stránce, který by byl vztažený na počet kliknutí na jednu návštěvu.

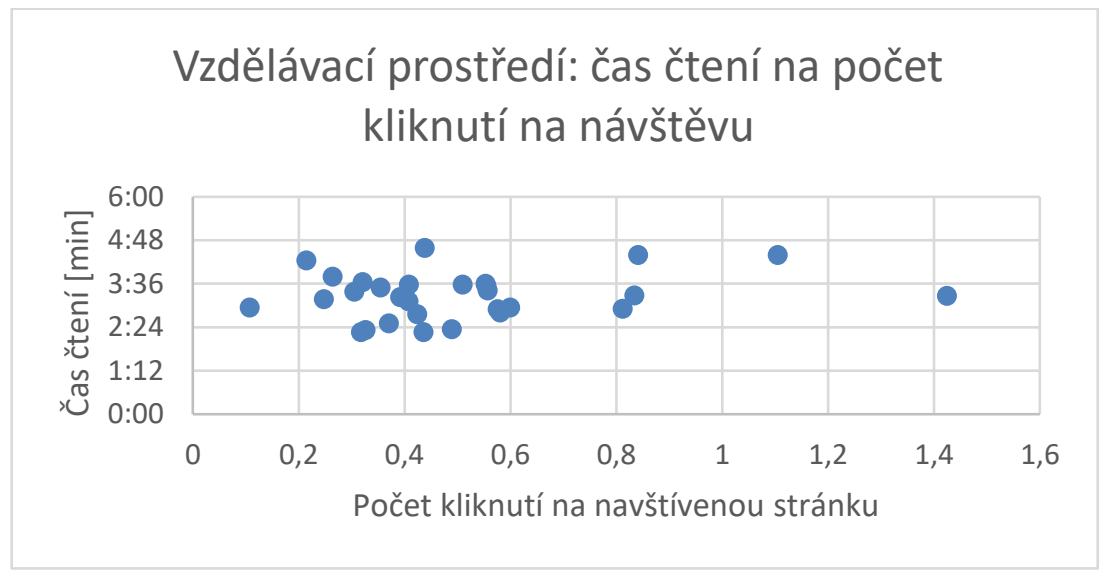

Graf č. 2: Vztah mezi časem čteni určité stránky (čas věnovaný kompetenci) a počet kliknutí na stránce.

Z grafu je patrné, že očekávanou závislost mezi časem stráveným na stránce (tedy zaujetím v časové doméně) a počtem kliků na jednu návštěvu (zaujetí obsahem natolik, že se chce student dozvědět něco více), vysledovat nemůžeme. Lze vidět jistou velice úzkou vazbu, ale rozhodně ne korelaci. Zajímavé je, že více se funkční závislosti (byt' stále se o korelaci nedá hovořit) blíží celkový počet zobrazených stránek místo času:

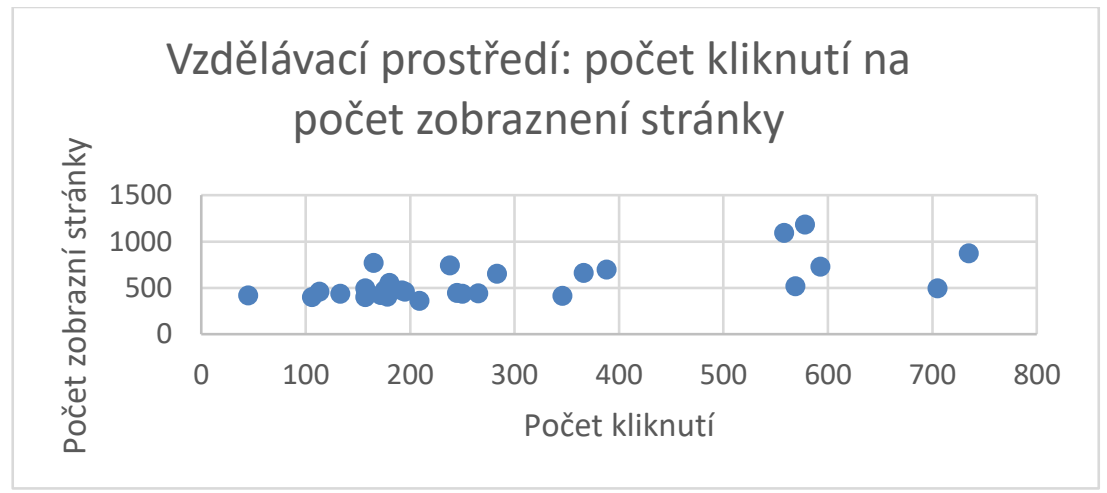

Graf č. 3: Vztah mezi počtem zobrazení stránky a počtu kliknutí na ní. 
Jediným, čistě environmentální vztahem je závislost počtu kliknutí na minutu čtení a návštěvu k počtu kliknutí a návštěvu, kde $\mathrm{R}^{2}=0,85$.

\section{Environmentální charakteristika}
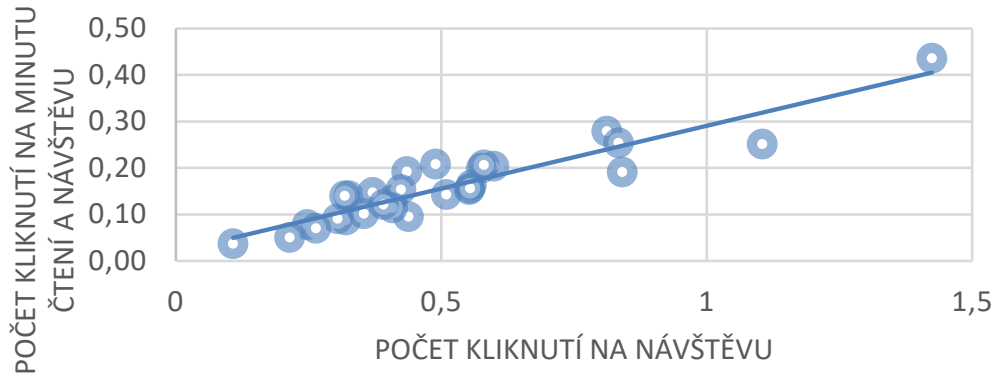

Graf č. 4: Vztah mezi počtem kliknutí vztaženého na jednu minutu čtení a počtem kliknutí na návštěvu. Tato závislost je přibližně lineární.

Nyní tedy může prristoupit $\mathrm{k}$ analýze jednotlivých položek - $\mathrm{v}$ následující tabulce kombinujeme výše uvedené údaje se sečteným časem získaného za doménu a počtem kliknutí za doménu. Čas je udávaný v sekundách, interakce s doménou je součtem všech analyzovaných interakcí, poslední sloupec je pak přepočítává na jednu návštěvu. Čas strávený na stránku je parametr, který zohledňuje skutečnost, že domény nejsou stejně bohaté na kompetence, takže napríklad první je nejkratší $(3+2$ položky) a druhá je nejdelší $(6+2$ položky).

Nejvíce času tráví u kompetence Ochrana zařízení (4:36), následované Vyhledáváním informací a Vytvářením digitálních objektů (4:24). Podle času stráveného v jednotlivých modelech by bylo možné formulovat hypotézu (kterou ale $\mathrm{v}$ rámci naší studie nemůžeme nijak verifikovat), že čas více než s reflexí kompetence nebo znalostmi souvisí s pocitem důležitostí či zaujetím tématem. To by vysvětlovalo také nadprůměrné časy u stránek s úkoly.

\begin{tabular}{|c|c|c|c|c|c|c|}
\hline Doména & $\begin{array}{l}n \\
0 \\
0 \\
0 \\
0 \\
0 \\
0 \\
0 \\
0\end{array}$ & 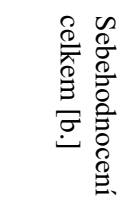 & 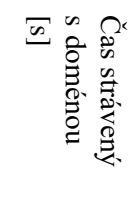 & 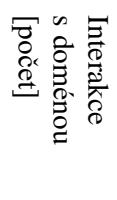 & 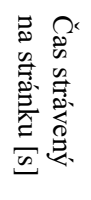 & 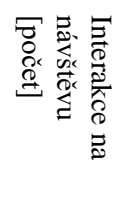 \\
\hline $\begin{array}{l}\text { Informační a datová } \\
\text { gramotnost }\end{array}$ & 65,9 & 4,5 & 931 & 2747 & 186,2 & 3,1 \\
\hline $\begin{array}{l}\text { Komunikace a } \\
\text { spolupráce }\end{array}$ & 64,5 & 4,2 & 1466 & 1782 & 183,3 & 3,5 \\
\hline $\begin{array}{l}\text { Tvorba digitálního } \\
\text { obsahu }\end{array}$ & 72,6 & 3,5 & 1171 & 1975 & 195,2 & 4 \\
\hline Bezpečnost & 72,8 & 3,6 & 1280 & 1313 & 213,3 & 2,8 \\
\hline Řešení problémů & 66,6 & 3,4 & 1248 & 638,0 & 208 & 1,4 \\
\hline
\end{tabular}

Tab. č. 4: Souhrnné výsledky analýzy dle jednotlivých domén. 
Z tabulky je možné vyčíst několik zajímavých korelačních vztahů (i vzhledem k počtu prvků bereme $\mathrm{v}$ potaz jen ty vyšší než 0,5$)$. Mezi správností odpovědí v testových otázkách a sebehodnocením je korelace $-0,6$, což lze interpretovat tak, že se studenti neumí adekvátně hodnotit. Domníváme se, že málo rozvinutá schopnost sebehodnocení a seberegulace se může opírat také o neschopnost hledat vlastní vzdělávací výzvy.

Z hlediska vlastního učebního chování a webové analytiky je zajímavá korelace - 0,7 , který je mezi sebehodnocením a celkovým časem stráveným na stánku. Jinými slovy - čím se v dané oblasti studenti cítí silnější, tím méně času stránce věnují, lze očekávat, že její obsah je pro ně snazší, tedy rychlejší na osvojení. Naopak pozitivní korelace je mezi časem stráveným na stránce a správnou odpovědí je didakticky cenná $(0,6)$. Lze ji zřejmě interpretovat tak, že čas strávený studiem dané dimense má pozitivní efekt na výsledek testu, což do značné míry odpovídá také jeho konstrukci.

\section{Klíčová zjištění}

Námi představená specificky konstruovaná př́ípadová studie se snažila ukázat, jakým způsobem studenti na digitální kompetence v rámci dvou studovaných kurzů nahlížejí. Ukazuje se, že výzkum edukačního prostředí u online kurzů prostředky webové analytiky je nesmírně zajímavý, ale současně není snadno interpretovatelný z hlediska výsledků ani autoevaluačního dotazníku, ani testu znalostního.

Jako nejproblematičtější kompetencí se jeví programování, které z hlediska všech dat vykazuje komplexně nejhorší výsledky v autoevaluačním dotazníku. Naměřená data také jednoznačně směřují $\mathrm{k}$ tomu, že uživatelé jsou součástí tzv. sítové generace (Jones et al., 2010; Kennedy et al., 2007).

Za zajímavé považujeme především zjištění, že ani studenti oboru informační studia a knihovnictví se nepovažují za odborníky na práci s informacemi do té míry, že by mohli efektivně pomáhat druhým nebo iniciovat nastavení informační procesů např́klad ve firmách. Stejně zarážející je fakt, že jejich schopnost reflektovat edukační proces (primárně ve vztahu k technologiím) je jednou z jejich nejslabších kompetencí. Skutečnost, že práce s informacemi je nezbytným předpokladem pro učení se v prostředí sítě (Candy 2004) je zcela evidentně pouhou implikací a nikoli ekvivalencí.

Data ukazují, že Google Analytics či Smartook je možné využít pro studium kvalitativních struktur na stránkách (co studenty na stránce nejvíce zaujalo), k analýze jejich technického vybavení (využitý prohlížeč, rozlišení obrazovky, připojení z mobilního zařízení) nebo třeba ke studiu studijních návyků (kdy se připojují, př́padně $\mathrm{k}$ jakým tématům se vracejí; jakým způsobem procházejí web).

Tento závěr v souladu s očekáváním z literatury (Luo, Rocco \& Schaad, 2015). Uvedená studie v závěru článku uvádí: „Zdá se, že služba Google Analytics je poměrně účinná př̀ poskytováni přehledu o procesu online učeni a při generováni souhrnných statistik, jako jsou relace, uživatelé, zobrazeni stránek, doba studia a míra okamžitých odchodu. “

Romanowski a Konak (2016) ve svém více technickém článku uvádějí: „Google Analytics odbornikuim dává př́ležitost využit analytický nástroj, který jim umožňuje sledovat a chápat chování uživatelů s jejich webovými stránkami a interpretovat ho, což vede $k$ možné optimalizaci. “ Optimalizací mají autoři na mysli především technické uspořádání stránek, jako jsou navigační menu, rozlišení obrazovky nebo obrázků. Také $\mathrm{v}$ tomto ohledu je možné dát autorům samozřejmě za pravdu, jde o informace dobře známé také z mimo edukačního prostředí. 


\section{Závěr}

V závěru bychom rádi zopakovali výsledky naší empirické studie vycházející ze struktury dané výzkumnými otázkami:

1) Jak sami sebe studenti v rámci digitálních kompetenci hodnotí?

Studenti mají evidentní problém sami sebe adekvátně hodnotit a výsledky, které z autoevaluace nabízejí odkazují ke zjevnému podhodnocení se, a to včetně kompetencí, které jsou přímo navázány na obor, který studují a $\mathrm{v}$ němž by se měli pohybovat nejméně 1-2 stupně výše. Sebehodnocení studentů v rámci obou kurzů dohromady vykazuje následující hodnoty: Informační a datová gramotnost $(4,5$ b.), Komunikace a spolupráce (4,2 b.), Tvorba digitálního obsahu (3,5 b.), Bezpečnost (3,6 b.) a Řešení problémů $(3,4$ b.) Škála hodnocení je v DigComp osmistupňová.

2) Souvisi toto hodnoceni s výsledky v testu?

Zjevnou souvislost mezi testovými otázkami a autoevalucí se prokázat nepovedlo. Tato skutečnost může být ovlivněna a) neschopností studentů se adekvátně hodnotit (což naznačují výsledky výše) a nebo b) nestandardizovaným testem.

3) Lze identifikovat domény kompetenci, nebo jednotlivé kompetence, ve kterých jsou studenti významně slabši či silnějši než v jiných?

Pokud bychom se přidrželi sebehodnocení, tak jednoznačně nejhůře dopadá Programování (2,5 b.), následované Řešením technických problémů (3 b.) a Nalezení mezer v digitálních kompetencích $(3,4$ b.). Jde o tři nejslabší kompetence, a především u programování je vidět celková negativní struktura odpovědí (vysoký počet odpovědí na stupni 0 b.). Naopak nad hranicí 4,5 b. se umístilo hodnocení informací (4,5 b.), Interakce skrze digitální prostředí (4,5b.) a Spolupráce skrze digitální technologie (4,7b.).

4) Lze identifikovat vztah mezi uživatelskou interakci se stránkou a výsledky testů či autoevaluace?

Poměrně významnou korelaci 0,6 můžeme identifikovat mezi časem stráveným na stránce a správnostmi odpovědí v testu, což na našem vzorku nemusí být representativní údaj, ale přesto jde o významné zjištění směřující $\mathrm{k}$ jednoduché možné analýze jednotlivých stránek. Naopak rostoucí míry sebehodnocení implikuje kratší čas strávený na stránce. Tato data mohou být silným protiargumentem proti tradiční skepsi vůči využívání Google Analytics.

\section{Literatura}

Calvani, A., Cartelli, A., Fini, A., \& Ranieri, M. (2008). Models and instruments for assessing digital competence at school. Journal of E-learning and Knowledge Society, 4(3), 183-193.

Candy, P. (2004). Linking thinking: Self-directed learning in the digital age.

Carretero, S., Vuorikari, R., \& Punie, Y. (2017). DigComp 2.1: The Digital Competence Framework for Citizens with eight proficiency levels and examples of use (No. JRC106281). Joint Research Centre (Seville site).

Cartelli, A. (2009). Frameworks for digital literacy and digital competence assessment.

In Proceedings of the 8th European Conference on e-Learning: ECEL (pp. 116-123).

Clifton, B. (2012). Advanced web metrics with Google Analytics. John Wiley \& Sons.

Cutroni, J. (2010). Google Analytics: Understanding Visitor Behavior. " O'Reilly Media, Inc.".

Černý, M. (2018). Využití nástrojů webové analytiky pro pochopení učení v online prostředí. ProInflow: Časopis pro informační vědy, 10(1). 
Elias, T. (2011). Learning analytics. Learning, 1-22.

Ferguson, R. (2012). Learning analytics: drivers, developments and challenges. International Journal of Technology Enhanced Learning, 4(5/6), 304-317.

Garrison, D. R., \& Kanuka, H. (2004). Blended learning: Uncovering its transformative potential in higher education. The internet and higher education, 7(2), 95-105.

Garrison, D. R., \& Vaughan, N. D. (2008). Blended learning in higher education: Framework, principles, and guidelines. John Wiley \& Sons.

Gilster, P. (1997). Digital literacy. New York: John Wiley.

Jiang, S., \& Rafeeq, A. (2018). Web-Based Course Delivery Approach in Teaching Mass Communication Courses. International Journal of Information and Education Technology, 8(6).

Jones, C., Ramanau, R., Cross, S., \& Healing, G. (2010). Net generation or Digital Natives: Is there a distinct new generation entering university?. Computers \& education, 54(3), $722-732$.

Kennedy, G., Dalgarno, B., Gray, K., Judd, T., Waycott, J., Bennett, S. J., ... $\&$ Churchwood, A. (2007). The net generation are not big users of Web 2.0 technologies: Preliminary findings.

Ledford, J. L., Teixeira, J., \& Tyler, M. E. (2011). Google analytics. John Wiley and Sons. Luo, H., Rocco, S., \& Schaad, C. (2015, October). Using Google Analytics to Understand Online Learning: A Case Study of a Graduate-Level Online Course. In Educational Innovation through Technology (EITT), 2015 International Conference of(pp. 264-268). IEEE.

Martin, A. (2005). DigEuLit - a European Framework for Digital Literacy: a Progress Report. Journal of Eliteracy, 2, 130-136. Retrieved June 2, 2009, from http://www.jelit.org/65/01/JeLit_Paper_31.pdf

Mc Guckin, C., \& Crowley, N. (2012). Using Google Analytics to evaluate the impact of the CyberTraining project. Cyberpsychology, Behavior, and Social Networking, 15(11), 625-629.

Muhametjanova, G., \& Akmatbekova, A. (2019). The Web-based Learning Environment in General Physics Course in a Public University in Kyrgyzstan. EURASIA Journal of Mathematics, Science and Technology Education, 15, 3.

Romanowski, B., \& Konak, A. (2016). Using Google Analytics to Improve the Course Website of a Database Course.

Siemens, G., \& d Baker, R. S. (2012, April). Learning analytics and educational data mining: towards communication and collaboration. In Proceedings of the 2nd international conference on learning analytics and knowledge (pp. 252-254). ACM.

Siemens, G., \& Long, P. (2011). Penetrating the fog: Analytics in learning and education. EDUCAUSE review, 46(5), 30.

Umbraco (2019). Dostupné z: https://umbraco.com/ (cit. 13.2.2019)

Veteška, J. (2008). Kompetence ve vzdělávání. GRADA.

Zlatuška, J. (1998). Informační společnost. Zpravodaj ÚVT MU, 8(4), 1-6. 